\title{
About the Artist and Illustrations
}

The drawings reproduced in this book were made by Wem Quirió Oro Nao' of Posto Indígena Santo André, the eldest son of Jimon Maram Oro Nao' and Quimoin Oro Eo. Wem Quirió is one of the best-educated and most articulate younger Wari', and he increasingly is called upon to serve as a leader representing his community in dealings with the government and other outside agencies. In 1987, when Wem Quirió was twenty-two, he worked with me for a period of several weeks compiling a list of vocabulary items in the Wari' language. Toward the end of our work together, he asked whether I would like him to draw pictures of some things that were iri' wari', "truly Wari'." I gave him the only drawing materials I had, typing paper and a set of felt-tipped pens in eight basic colors, and told him to draw whatever he chose. Among the sketches he produced were scenes of precontact funerals and the giving of gifts to a slain peccary, which appear in Chapters 4 and Io. In I999, at my request, he redid some of his earlier pictures as line drawings in black ink to make them easier to reproduce in this book.

Wem Quirió was born in 1966 and never witnessed precontact funerals himself. He based his sketches on what he had heard older people describe. We showed his drawings to a number of older men and women who had participated in precontact funerals and asked for their feedback. Everyone who saw the sketches expressed enthusiastic approval, except for two details of body adornment that elders identified as inauthentic. Wari' had no clothing before the contact, but when Wem Quirió's mother saw his drawings, she told him she thought his drawings of male genitals were immodest. To please his mother, he added loincloths to some of the figures. Elders also criticized the fact that people in the scene with the slain peccary were shown wearing scarlet macaw feathers. Aside from this, everyone who saw the drawings agreed that they were good representations of scenes from the past. I thank Wem Quirió for his permission to reproduce his drawings here and hope that this will bring favorable recognition for his work and for the efforts he and others in the rising generation of younger Wari' have undertaken to look for new paths toward a future that will assure their people's well-being and cultural survival. 